\title{
Um panorama jurídico e sociopolítico do imigrante do MERCOSUL no Brasil
}

\section{Gabriel Casnati ${ }^{1}$}

\section{Resumo}

O principal objetivo do presente trabalho é discutir, com base nas teorias críticas sobre o tema, a condição dos imigrantes trabalhadores no âmbito do MERCOSUL, com especial enfoque naqueles vindos dos países periféricos do bloco no Brasil. Nesse sentido, o artigo dispõe, tanto sobre os imigrantes legais quanto sobre os ilegais, razão pela qual será necessário diferenciar as consequências dessa forma de distinção, mapeando as principais dinâmicas que ocorrem na região atualmente, as ocupações de trabalho e as principais dificuldades sociojurídicas enfrentadas em território brasileiro pelos imigrantes. Assim, analisou-se a perspectiva histórica recente das ondas migratórias dentro do MERCOSUL, suas assimetrias e a atuação do Brasil nesse quesito no século XXI, tendo como pano de fundo os tratados internacionais sobre migrações e direitos dos trabalhadores dos quais o País é signatário. Para esse fim, utilizou-se o método indutivo amparado por ampla pesquisa bibliográfica e documental.

Palavras-chave: Imigrante - Direitos Fundamentais - MERCOSUL.

\section{Abstract}

The main goal of this work is to discuss, the conditions of Mercosur immigrant workers in Brazil, with special attention to those from the bloc's peripheral countries, and based on the critical theories on the subject. In this sense, the paper will address both legal and illegal immigrants, which is why it will be necessary to differentiate the consequences of this form of distinction by mapping the main dynamics that occur in this region, the work opportunities, and the main socio and legal difficulties faced by immigrants in Brazil. Therefore, it will analyze the recent historical perspective of migratory waves within Mercosur, its asymmetries and lack of integrated public policies, and Brazil's role in this regard in the twenty-first century, with the backdrop of the international treaties on migration and rights of workers to which the country is a signatory. For this purpose, the inductive method has been used, supported by extensive literature and desk research.

Keywords: Immigrant - Fundamental rights - MERCOSUR.

1 Bacharel em Relações Internacionais pela Pontifícia Universidade Católica de São Paulo. Contato: gabrielcasnati@gmail.com 


\section{Introdução}

Em linhas gerais, é possível constatar que as relações migratórias entre os países sulamericanos alteraram-se de forma significativa nas últimas décadas, tanto no que diz respeito à origem dos fluxos como em relação ao saldo migratório regional e às legislações que regulamentam essa temática no continente. Nesse contexto, a criação do Mercosul, em 1991, em maior ou menor escala, estimulou a interação entre os Estados e foi uma das instâncias que moldaram o atual cenário migratório na América do Sul.

O Brasil, maior potência da região, a partir da criação do Mercosul, deixou de se caracterizar como um país majoritariamente exportador de migrantes em direção a países desenvolvidos e voltou a ser um grande receptor de estrangeiros, principalmente advindos de países africanos e latinos. Nesse sentido, foi o país da região no qual os fluxos migratórios internacionais mais se intensificaram nas últimas décadas.

Ainda que existam diversas pesquisas consistentes sobre o tema, a velocidade e a complexidade de alteração dessas dinâmicas fazem com que os trabalhos acadêmicos ainda sejam insuficientes para a compreensão integral desse cenário. Partindo deste pressuposto, o presente artigo, utilizando-se do método indutivo, teve como objetivo traçar uma revisão bibliográfica sintética sobre o panorama jurídico e social da condição do trabalhador imigrante no Mercosul e no Brasil com base em artigos acadêmicos de toda a região e fontes primárias de vieses distintos. Assim, o trabalho - que tem como ponto de partida uma breve contextualização dos fluxos migratórios dentro do Mercosul nas últimas duas décadas propõe-se a expor um balanço sintético dos avanços, impasses e contradições das políticas públicas migratórias no âmbito doméstico brasileiro e do Mercosul.

\section{Ondas migratórias do século XXI para o Mercosul}

A partir de meados da década de 90 do século XX, os países do Mercosul alteraram substancialmente sua relação de imigração com o resto do mundo. Se durante boa parte do século passado a região caracterizou-se pela saída de pessoas rumo aos países desenvolvidos da América do Norte e Europa, hoje já é possível afirmar que esse fluxo diminuiu consideravelmente, ao passo que se tornou uma área de recepção de imigrantes de países 
subdesenvolvidos, além de o próprio fluxo dentro do bloco ter aumentando de modo significativo a partir da criação do Mercosul (PATARRA, 2005).

Os números apresentados por Fernandes (2015, p. 28) demonstram essa alteração da tendência no Brasil. Segundo eles, entre 1990 e 2000 diminuiu o número de imigrantes no total da população brasileira, embora o número de estrangeiros provenientes do Mercosul tenha aumentado. Enquanto isso, entre 2000 e 2010, a taxa de estrangeiros no Brasil cresceu mais uma vez entre os nascidos em países do Mercosul e vindos de países não europeus, mesmo sem mensurar os milhares de imigrantes ilegais. Os números mais recentes em relação aos estrangeiros regulamentados talvez sejam os disponibilizados pela Polícia Federal, que, no intervalo de 2006 a 2012, documentou um crescimento de 34\% no número de imigrantes, passando estes de 1.175 .353 para 1.575 .643 pessoas.

No ano que marcou a assinatura do Tratado de Assunção, que deu origem ao Mercosul, o saldo de migrações no Brasil foi negativo em cerca de 1,8 milhões de pessoas. De lá pra cá, a maioria da doutrina aponta tanto questões domésticas quanto regionais e internacionais para a rápida reversão da tendência de emissão de imigrantes da América do Sul para os países desenvolvidos (SALA; CARVALHO, 2008).

No aspecto internacional, dois acontecimentos desestimularam o fluxo da América do Sul para os Estados Unidos e Europa. Primeiramente, os atentados de 11 de setembro deram início a uma nova postura de Washington em relação à imigração proveniente, principalmente, de países subdesenvolvidos, passando a tratar a questão como problema estritamente de segurança nacional, o que, sem dúvida, colocou mais barreiras para os trabalhadores imigrantes se assentarem no país. Pelo aspecto econômico, a crise de 2008 foi outro grande ponto de virada, já que, além de representar uma diminuição razoável na oferta de empregos e na deterioração da qualidade de vida dos trabalhadores de baixa renda nos países desenvolvidos, naquele momento a maioria dos países latino-americanos estava em meio a seus processos de crescimento econômico (FERNANDES, 2015).

Em relação às alterações regionais, a criação do Mercosul possibilitou novas opções para os trabalhadores migrantes da região em razão, principalmente, das facilitações do trânsito de trabalhadores entre os países membros. Além disso, no ano de 2005 foi firmado o acordo de regularização migratória entre Brasil e Bolívia, que facilitou o processo de legalidade entre os nacionais desses países mediante certos requisitos mínimos. Ademais, durante toda a década de 1990, a Argentina, país que historicamentefoi a principal rota de imigrantes advindos dos países latinos, em razão da proximidade cultural e geográfica, sofreu 
com a queda de seu produto interno bruto (PIB), consecutivas trocas presidenciais e elevados níveis de desemprego. Por outro lado, é inegável que, de meados da década de 1990 até 2010, o Brasil, principal potência regional, cresceu economicamente e alavancou sua projeção internacional, atraindo, assim, a atenção dos imigrantes (SALA; CARVALHO, 2008; FERNANDES, 2015).

Como fenômeno recente, esse novo fluxo de trabalhadores latinos rumo ao Brasil, que conta com muitos estrangeiros não regularizados, ainda é carente de dados. Por isso, o presente artigo optou por recortar seu objeto na cidade de São Paulo, já que a disponibilidade de dados é muito maior em relação às demais cidades do País. A metrópole, segundo a Polícia Federal, recebeu mais de 51\% dos imigrantes que chegaram ao Brasil desde 2006 e concentra o maior acervo de estatísticas e estudos de campo recentes (FERNANDES, 2015).

Nos últimos anos, destacou-se, em São Paulo, a chegada de imigrantes trabalhadores provenientes do Peru, Paraguai e Bolívia. Em linhas gerais, esses trabalhadores apresentam características sociais semelhantes - em sua maioria, mão de obra jovem e de baixo nível educacional, que geralmente trabalha no setor têxtil. Dada a grande vulnerabilidade social desses grupos e a atuação de redes clandestinas de transporte e obtenção de emprego, os provenientes desses três países também encabeçam as denúncias de tráfico de pessoas do Centro de Apoio ao Migrante de São Paulo (Cami). Entre julho de 2005 e julho de 2008, passaram mais de 20 mil imigrantes, de vinte nacionalidades, dentre os quais $90 \%$ provinham da Bolívia, 3,5\% do Paraguai e 3\% do Peru (PERERA, 2010; ILLES; TIMÓTEO; FIORUCCI, 2008).

Em relação aos provenientes do Paraguai, Perera (2010) mostra que os paraguaios destacam-se por terem o maior potencial migratório entre os países do Mercosul com destino aos Estados do próprio bloco. Sala e Carvalho (2008) apontam a elevada concentração de terras, junto à pobreza e ao alto índice de fertilidade do país, como principais fatores da imigração. Segundo eles, pelo caráter fortemente agrário da população, os paraguaios concentram-se em regiões agrícolas e fronteiriças do Brasil. Entretanto, essa tendência vem se modificando, principalmente pelos grandes fluxos de nacionais deste país que são atraídos pelo polo empregatício das capitais do centro-sul brasileiro, com ênfase em São Paulo. Em 2000, ano do último levantamento, 36,9\% dos paraguaios viviam no Paraná, 26,5\% no Mato Grosso do Sul e 14,4\% em São Paulo. 


\section{Imigrantes legais e imigrantes ilegais no Mercosul}

Da mesma maneira que ocorre com qualquer outro tipo de fluxo ilícito, a imigração ilegal é extremamente difícil de ser quantificada ou mapeada. Com o aumento deste fluxo, junto com a grande diversificação de nacionalidade dos trabalhadores imigrantes provenientes de países subdesenvolvidos rumo ao Brasil, a literatura ainda não deu conta de analisar todas as rotas, motivações, aliciamento e os números exatos desses estrangeiros em situação irregular.

O trabalho de Illes, Timóteo e Fiorucci (2008), focado nas dinâmicas migratórias da capital paulista, traça com precisão o mercado ilegal laboral no qual se inserem, na maioria das vezes, esses imigrantes, e esforça-se na tentativa de estimar os números deste fluxo. No ano da publicação, os autores apontam cerca de 1.250 mil imigrantes regulamentados na cidade, ao passo que esse número aumentaria para mais de dois milhões se somadosos clandestinos - em sua maioria latinos. Segundo eles, a ilegalidade desses trabalhadores sustenta a economia que explora mão de obra barata na cidade.

Esse setor, embora tenha sido alvo de pressão social nos últimos anos, continua sendo invisível ao poder público. Em suas rotas de chegada ao Brasil, tem-se, no contrabando de imigrantes e no tráfico de pessoas, fatos comuns na história desses trabalhadores. A mão de obra barata do estrangeiro ilegal é explorada em diferentes setores da economia clandestina, que se baseia em remunerações abaixo do salário mínimo nacional, jornadas de trabalho exaustivas, condições insalubres e coerção (CACCIAMALI; AZEVEDO, 2005).

No caso brasileiro, em razão das peculiaridades históricas e sua legislação atual, quando se trata da oposição entre imigrantes legais versus ilegais, é fundamental ter noção da seletividade da concessão de regulamentação em relação aos estrangeiros, em função, principalmente, de sua origem social - que, no caso, se mistura com a nacionalidade - e de gênero. Dessa grande seletividade, tem-se que, entre 2005 e 2011, o número de autorizações de residência permanente concedidas pelo governo brasileiro foi de apenas $6 \%$ do total de requerimentos: apenas 17.749 entre 294.215 casos (VILELA; SAMPAIO, 2015).

De maneira complementar, os dados compilados por Vilela e Sampaio (2015) escancaram o caráter seletivo desse processo. Segundo os números dessa mesma época, as nacionalidades que mais receberam autorizações foram, em ordem decrescente: Estados Unidos, Filipinas, Grã-Bretanha, Índia, Alemanha, China, França, Itália, Japão, Noruega, Indonésia, Espanha, Canadá, Holanda e Portugal. Das quinze nacionalidades citadas, onze 
compõem a Organização para Cooperação e Desenvolvimento Econômico (OCDE) - bloco dos países mais ricos do mundo -, enquanto as outras são nacionalidades asiáticas. Por sua vez, o país do Mercosul com mais permissões é a Argentina, enquanto os bolivianos, maior comunidade migrante no Brasil, não representaram nem 1\% das concessões emitidas.

Para consolidar sua tese, os autores supracitados apontam alto grau de escolaridade entre os imigrantes legais. Segundo eles, $60,4 \%$ possuem ensino superior completo ou mais, enquanto $39,3 \%$ possuem ensino médio ou superior incompleto. No mesmo caminho, 90,6\% das permissões de trabalho emitidas foram para homens. Por último, o artigo ainda aponta que esses números, tanto de escolaridade como de nacionalidade e gênero, mantiveram-se de forma constante entre 2005 e 2011, o que assegura o caráter seletivo da política migratória brasileira (VILELA; SAMPAIO, 2015).

Embora a legislação do Brasil sobre o tema não seja discriminatória, a contextualização histórica e política e a análise do texto da principal lei que rege o tema, o Estatuto do Estrangeiro, apontam nesse sentido. A lei, criada em pleno estado de exceção, no ano de 1980, em meio à ditadura civil-militar, dá ênfase ao paradigma da segurança nacional, que enxerga o estrangeiro como uma potencial ameaça.

O Estatuto, em seu artigo 16, explicita que não possui nenhum tipo de caráter social, uma vez que define como objetivo primordial da imigração o de proporcionar mão de obra para o desenvolvimento nacional. O artigo 65, por sua vez, aponta que o estrangeiro pode ser expulso por "atentar contra a segurança nacional" ou por "entregar-se a vadiagem ou a mendicância". Essa retórica mercadológica, com delimitações amplas, é o que confere ao Estado margem de interpretação e legitimidade de selecionar, segundo critérios subjetivos de "interesse nacional”, os imigrantes considerados bem-vindos. Para selar a demarcação da diferença de direitos entre nacionais brasileiros e estrangeiros, o Estatuto do Imigrante proíbe o estrangeiro de deter a posse de meios de comunicação e não permite, em regra, o voto em nenhuma instância, entre outras restrições ${ }^{2}$ (ALMEIDA, 2015).

No ano de 2009, o então presidente Luís Inácio Lula da Silva sancionou a Lei de Anistia Migratória. Sem dúvida, o programa foi um passo positivo na vida dos cerca de 41 mil estrangeiros que lograram suas regularizações. Entretanto, para além de seu alcance limitado - pode-se afirmar que a grande maioria dos imigrantes irregulares não foi atingida pelo

2 Existem exceções ao Estatuto do Estrangeiro, como o Tratado de Amizade, Cooperação e Consulta entre a República Federativa do Brasil e a República Portuguesa, assinado em 2000, que, a partir do Artigo 12, define que os portugueses no Brasil "gozarão dos mesmos direitos e estarão sujeitos aos mesmos deveres dos nacionais desses Estados” (BRASIL, 2001). 
programa -, a lei sinaliza o caráter das políticas migratórias brasileiras, dado que o Estado somente concedeu o perdão às pessoas consideradas ilícitas de forma paliativa. Ou seja, a anistia migratória em nada alterou o paradigma vigente, uma vez que o Brasil continuou a não reconhecer institucionalmente o direito humano universal de migrar (SOUCHAUD, 2012).

Em relação aos demais ordenamentos jurídicos do Mercosul, a legislação paraguaia, criada na época da ditadura de Stroessner, assemelha-se estruturalmente à brasileira. Por outro lado, Uruguai e Argentina destacam-se por leis recentes que, embora incompletas, incorporam outro paradigma sobre a questão migratória, com a ampliação de direitos aos imigrantes.

O caso argentino é mais emblemático por se tratar de outro país do bloco com grande fluxo de estrangeiros provenientes de países vizinhos. A Ley de Migraciones, de 2004, garante juridicamente ao imigrante os mesmos direitos trabalhistas aplicáveis aos argentinos. O primeiro aspecto importante desta lei é que ela confere um status especial aos trabalhadores estrangeiros advindos de outros países do Mercosul. Outro ponto significativo concerne às questões trabalhistas. Embora a temática de organização sindical não apareça na lei, a Convención internacional sobre la protección de los derechos de todos los trabajadores migratorios y de sus familiares, assinada pela Argentina, garante ao estrangeiro todos os meios de organização sindical, além de proteger os direitos laborais de forma equitativa (FERNANDES, 2013).

Em seu artigo 14, a lei demonstra outro sinal de avanço em relação ao paradigma predominante no continente, preocupando-se com a incorporação do imigrante na sociedade argentina. No mesmo caminho, a legislação eleitoral prevê que o Estado deve facilitar a presença estrangeira nas decisões públicas, cabendo a cada província decidir em quais pleitos e quais os requisitos para os imigrantes votarem. Para as eleições nacionais, os imigrantes ainda são proibidos de votar (FERNANDES, 2013).

Como contraponto ao otimismo provocado pela Ley de Migraciones argentina, o trabalho de Fernandes (2013) também deixa claro que ela ainda contém suas limitações, contradições e falta de interesse político para implantação efetiva de certas políticas públicas de maior orçamento. Como exemplo, pode-se citar a proibição legal de exercício de qualquer atividade remunerada pelo imigrante clandestino - ideia oposta à dos tratados assinados pelo país - e a falta de investimentos necessários para implantação de programas de inclusão e proteção dos direitos. 


\section{Políticas públicas nos âmbitos trabalhista e previdenciário para os imigrantes}

Em sua breve história, o desenvolvimento do Mercosul é comumente dividido pela doutrina em dois períodos distintos. O primeiro, de 1991-2001, teve caráter meramente comercial, de vertente neoliberal. O segundo, iniciado em 2002 e, segundo Culpi (2015), com término em 2012, foi marcado por uma guinada à esquerda nos governos nacionais do bloco sob uma lógica pós-liberal não homogênea.

O Tratado de Assunção já demonstrava claramente que não tinha como objetivo, naquele momento, coordenar políticas migratórias em conjunto. No acordo, não existe nenhuma referência específica à questão, tampouco alguma comissão ou subgrupo que aborde o tema. Dentro da Declaração Sociolaboral, datada de 1998, há uma referência à igualdade de direitos para todos os trabalhadores, dentro ou fora de seu Estado de origem, além de duas diretrizes para incentivar a geração de empregos entre os países do bloco. Porém, com base na doutrina sobre o tema, torna-se evidente que nenhuma medida efetiva foi tomada para garantir esses objetivos.

Na mesma direção, foi apenas durante o final da década de 1990 que os fluxos entre os países latino-americanos começaram a despontar numericamente e chamar a atenção da opinião pública, sendo debatidos, segundo Culpi (2015), principalmente como problema de segurança pública nacional, o que refletiu nos acordos aprovados sobre o tema, tais como a Acordo sobre Tráfico Ilícito de Migrantes entre os Estados Partes do Mercosul, aprovado no ano de 2004.

As mudanças no tratamento do tema deram-se apenas em 2002. Com uma conjuntura político-econômica positiva e convergente entre a maioria dos países da região, o viés da integração latino-americana no sentido sociocultural foi fortemente alavancado, principalmente por Brasil e Argentina, e, posteriormente, pelos demais países do Mercosul expandido, ou seja, também pelos países associados ${ }^{3}$.

Logo nos primeiros anos desse novo momento do Mercosul foram criados espaços de discussão social em diversas instâncias da instituição,como o Foro Especializado Migratório

\footnotetext{
Hoje, todos os países da América do Sul são membros associados ou plenos do Mercosul. Os membros plenos - ou Estados-parte - são os países que assinaram o Tratado de Assunção, em 1991, mais a Venezuela, que ingressou em 2012. Por outro lado, para tornar-se um Estado associado é necessária a assinatura de acordos bilaterais com o bloco. Chile, Peru, Equador, Colômbia, Guiana e Suriname estão nessa categoria, enquanto a Bolívia está em processo de adesão para tornar-se o sexto Estado-parte.
} 
da Reunião de Ministros do Interior do Mercosul, em 2003, e a Conferência Sul-Americana sobre Migrações, em 2010.

Nesse contexto, podemos destacar dois acordos fundamentais para o avanço de políticas públicas na região. Primeiramente, o Acordo sobre Residência dos Nacionais dos Estados-Parte, que, nas palavras de Vichich (2015),

\begin{abstract}
garante os direitos civis, sociais, econômicos e culturais. O direito a trabalhar é tema central de suas cláusulas: no artigo 9 , estabelece que os cidadãos do Mercosul e suas famílias que tenham obtido residência nos termos do presente Acordo gozarão "dos mesmos direitos e liberdades civis, sociais, culturais e econômicas [...] entrar, permanecer, transitar e sair do território das Partes; associar-se com fins lícitos ${ }^{4}$. (VICHICH, 2015, p. 116, tradução minha).
\end{abstract}

Segundo o autor, a questão-chave resolvida pelo acordo é a irregularidade migratória dos trabalhadores, que leva ao trabalho ilegal por meio da exploração e do tráfico de pessoas. Entretanto, não alcança mudanças para resolver a situação dos trabalhadores de fronteira, uma vez que ele obtém sua residência em um país e atravessa a fronteira cotidianamente para trabalhar.

No mesmo sentido, ele também aponta o Acordo Multilateral de Seguridade Social do Mercado Comum do Sul, que entrou em vigor no Brasil em 2006, cujo primeiro objetivo é garantir, de fato, a livre circulação dos trabalhadores. Embora a livre circulação já seja garantida por lei, é sabido que as famílias trabalhadoras estrangeiras sofrem discriminação por parte do Estado. Sendo assim, uma harmonização previdenciária entre os países serve, sem dúvidas, para reduzir consideravelmente a vulnerabilidade do migrante.

Tendo em vista esse cenário a partir do ano de 2002, de maior pró-atividade dentro do Mercosul no que diz respeito à matéria de tratados de cunho social, é importante distinguir os acordos assinados das políticas públicas de fato implantadas, que variam de acordo com o país.

No caso do Brasil, maior Estado do Mercosul, com papel crucial no estímulo à elaboração de políticas dos demais países, com base em Lussi (2015), a burocratização e a criminalização da migração continuaram no cotidiano dos trabalhadores migrantes em razão

\footnotetext{
4 "garantiza los derechos civiles, sociales, económicos y culturales. El derecho a trabajar tiene centralidad en sus cláusulas: en el artículo 9, establece que los ciudadanos del MERCOSUR y sus familias que hubieren obtenido residencia en los términos del presente Acuerdo gozarán "de los mismos derechos y libertades civiles, sociales, culturales y económicas [...] entrar, permanecer, transitar y salir del territorio de las Partes; [...]asociarse con fines lícitos".
} 
da legislação desatualizada. Ela aponta que, embora se tenha avançado significativamente na matéria migratória dentro do bloco, no Brasil ainda existem os mesmos entraves em relação ao acesso à informação e à aplicação dos acordos ratificados em nível regional. Já Câmara (2014) confirma essas problemáticas ao pesquisar os órgãos nacionais de imigração e concluir que existe o conhecimento da retrógrada lei atualmente vigente, ao mesmo tempo em que há o reconhecimento de diversos projetos de políticas públicas que ainda não saíram do papel.

Analisando casos práticos, a questão do Sistema Único de Saúde brasileiro (SUS) para estrangeiros sintetiza bem as limitações e contradições em que a política migratória do País está inserida. Pelo fato de o SUS tratar-se, provavelmente, do programa social consolidado mais universal do Brasil, ele nos dá um bom indício da relação do estrangeiro com os serviços públicos nacionais.

O artigo de Giovanella et al. (2007) contribui significativamente para fazer o mapeamento dessa questão. Com base nas respostas de secretários de saúde de cidades em região de fronteira, os autores apontam que $75 \%$ dessas cidades fazem o atendimento regular desses estrangeiros, sendo em $36 \%$ dos casos frequente ou muito frequente. Vale apontar que, ao contrário do que apontam muitos estereótipos pejorativos, a demanda de brasileiros ainda é consideravelmente superior.

A maior complexidade do assunto surge a partir das distintas definições de estrangeiro dadas pelos secretários municipais de saúde e que, pelo fato da retrógrada legislação brasileira em relação aos imigrantes não assegurar nenhum direito, faz com o que cada cidade lide de diferentes formas em relação à obrigatoriedade de prestar atendimento a um estrangeiro. Dessa forma, o artigo aponta que $70 \%$ dos secretários municipais de saúde afirmam que todos os estrangeiros têm acesso ao atendimento, ao passo que somente $36 \%$ afirmaram que prestam atendimento para todos os serviços do SUS e a qualquer momento (GIOVANELLA et al., 2007).

No mesmo sentido, apontam ainda os autores que em $69 \%$ dos atendimentos são exigidos documentos de identidade e em $49 \%$ também o comprovante de residência, pelo que ficam claras as imensas barreiras burocráticas que restringem o acesso de estrangeiros e brasileiros não residentes. Nesse sentido, as contradições jurídicas, a dubiedade das classificações e a falta de coordenações regionais de saúde, fazem com que, além de não ter certeza da possibilidade de ser atendido, seja impossível dar continuidade ao atendimento acompanhado, o que coloca muitas vidas em risco. 
Na contramão dessa tendência, a prefeitura da cidade de São Paulo, na gestão de Fernando Haddad, criou, em 2013, a primeira coordenação municipal de políticas para migrantes do País. Embora tenha muitas limitações políticas e orçamentárias, além de criar um modelo que pode inspirar outras cidades, a coordenadoria tomou medidas básicas importantes para o acolhimento aos estrangeiros, tais como a construção de novos abrigos para estrangeiros em condição de vulnerabilidade em parceria com instituições como a Missão Paz e a organização não governamental (ONG) Serviço Franciscano de Solidariedade. Outra iniciativa foi a criação de contas bancárias na Caixa Econômica Federal para estrangeiros, que, antes vedados deste acesso, comumente sofriam furtos em suas residências por não terem onde guardar o dinheiro vivo.

Embora esses avanços devam ser pontuados, é imprescindível apontar a imensa lacuna que existe na cidade em relação às políticas públicas para os imigrantes. Por exemplo, como mostra Fernandes (2013), nas escolas municipais, os casos de bullying envolvendo paraguaios e bolivianos - as duas nacionalidades mais presentes na rede pública -e a dificuldade de material exclusivo dificultam e desestimulam a presença estrangeira nas escolas.

Com o panorama traçado até o momento, é possível inferir que, diferentemente da primeira década do bloco, o segundo período, que se iniciou a partir de 2002, contribuiu significativamente para a criação de políticas regionais sobre imigração. Entretanto, como aponta Culpi (2015), ocorreram poucos avanços no que se refere aos compromissos de efetiva harmonização da legislação e na ampliação, na prática, dos direitos. O caso brasileiro do SUS ilustra bem os empecilhos jurídicos e burocráticos, a falta de vontade política e a pouca coordenação regional nos temas sociais. Por outro lado, a inédita iniciativa por parte da prefeitura de São Paulo abre margem para "driblar" a retrógrada lei de migrações do Brasil que dificilmente será alterada em tempos de crise político-econômica -, mostrando que é possível estimular a elaboração de políticas públicas de impacto por meio da administração municipal.

\section{Instrumentos de combate ao trabalho escravo e ao tráfico de imigrantes no Mercosul}

Mesmo que o tráfico de imigrantes não se caracterize como um fato novo, a bibliografia aponta que esse tipo de violação de direitos humanos fundamentais, além de ter se diversificado, também se profissionalizou nas últimas décadas. Com o aumento dos fluxos migratórios internacionais, junto ao acréscimo no número de denúncias de tráfico humano, a 
comunidade internacional somente reconheceu o caráter universal e cooperativo no combate à questão ao longo dos anos 1990, o que acarretou a aprovação da Convenção das Nações Unidas contra o Crime Organizado Transnacional, mais conhecido como Protocolo de Palermo, no ano 2000.

Nesse sentido, muitos autores, como Cacciamali e Azevedo (2005), apontam que o caráter proibitivo no âmbito das migrações e a lógica trabalhista neoliberal são os principais motivos que sustentam essa grande rede de aliciamento ilegal de humanos.Essa parte do trabalho pretende avaliar sucintamente até que ponto as novas formas de combate à questão, iniciadas em 2000, são eficazes no sentido de diminuir significativamente o problema ou resolver essa contradição inerente ao combate a este tráfico dentro do paradigma proibicionista na realidade do Mercosul.

Por se tratar da primeira iniciativa internacionalmente coordenada sobre o tema, o Protocolo de Palermo significou, por si só, um importante avanço, assegurado pelo alto índice de adesão (118 Estados). Em seu artigo $3^{\circ}$, o documento estabelece a definição do tráfico de seres humanos e algumas de suas modalidades:

\begin{abstract}
o recrutamento, o transporte, a transferência, o alojamento ou o acolhimento de pessoas, recorrendo à ameaça ou uso de força ou a outras formas de coação, ao rapto, à fraude, ao engano, ao abuso de autoridade ou à situação de vulnerabilidade ou à entrega ou aceitação de pagamentos ou benefícios para obter o consentimento de uma pessoa que tenha autoridade sobre outra, para fins de exploração. Exploração inclui, no mínimo, a exploração da prostituição, ou outras formas de exploração sexual, trabalho ou serviços forçados, escravidão ou práticas análogas à escravidão, servidão ou a remoção de órgãos. (BRASIL, 2004).
\end{abstract}

Junto ao estabelecimento de uma definição mais concisa, o Protocolo ainda assinala que, embora o foco seja com relação às mulheres e crianças, qualquer pessoa pode ser vítima. Assim, o documento marca uma nova forma de enxergar o tráfico, em que a proteção da vítima e a prevenção dos casos aparecem como eixos fundamentais (BIJOS, 2009). Em relação ao último objetivo, em poucos anos a questão do tráfico de pessoas passou a entrar no centro do debate de organismos internacionais relacionados ao tema. Como exemplo, é possível citar as Convenções 29 e 105 da Organização Internacional do Trabalho(OIT) sobre o trabalho forçado; a 97 e a 143, que trazem as formas de proteção do trabalhador migrante contra a exploração laboral.

Entretanto, o Protocolo de Palermo não pode ser caracterizado apenas por avanços. Bijos (2009), por exemplo, aponta que o Protocolo se contradiz em relação à necessidade do 
uso da força na caracterização do tráfico ou não. Essa lacuna na definição torna-se um grave problema no entendimento da questão, resultando em distintas interpretações. Outro problema grave, segundo ele, é em relação ao tráfico de pessoas versus imigração ilegal. Isso porque, com base no Protocolo contra o Contrabando de Migrantes por Terra, Mar e Ar, de 2000, documento complementar ao de Palermo, o tráfico de pessoas é definido independentemente do uso da força (BRASIL, 2004b). Assim, esse tipo de crime deixa de ser intrinsecamente um crime de direitos humanos e passa a ser uma questão de violação de leis migratórias nacionais. Essa contradição é o cerne do debate migratório atual e, embora o Protocolo de Palermo tenha aberto oportunidades ineditamente importantes para o combate ao tráfico humano, ele se torna insuficiente por não resolver a origem dos motivos que tornam o contrabando de imigrantes um negócio com alta demanda e grande lucratividade.

No âmbito do Mercosul, os paísesmembros rapidamente ratificaram as convenções e os protocolos sobre a temática, o que alavancou as medidas de combate ao tráfico de imigrantes. Esses países, além de internalizarem, integral ou parcialmente, o Protocolo, passaram a debater medidas em conjunto. A única exceção refere-se a uma importante convenção que, do bloco, somente o Brasil não ratificou: a Convenção Internacional sobre a Proteção dos Direitos de Todos os Trabalhadores Migrantes e dos Membros das suas Famílias. O fato de esta convenção ser contraditória ao Estatuto do Imigrante - como por garantir direito à associação - dificulta sua tramitação no Congresso e seu impacto doméstico é extremamente negativo para a população migrante, pois não existe a garantia de defesa dos direitos ali defendidos.

A primeira medida no âmbito do Mercosul que observa a questão do tráfico de imigrantes por um viés mais amplo que o da segurança pública foi a Declaração de Montevidéu, do ano de 2005, contra o tráfico de pessoas - crianças, adolescentes e mulheres para fins de prostituição. Dentro da Organização dos Estados Americanos (OEA), no ano seguinte, foi elaborado o Documento Declarativo de Recomendaciones Generales y Específicas para Prevenir, Combatir y Sancionar La Trata de personas y para La Protección Integral de Sus Víctimas, que serviu de base para planos nacionais no combate ao tráfico humano. Por sua vez, em 2008 foi criado o primeiro Centro de Coordenação de Capacitação Policial do Mercosul (BIJOS, 2009; OIT, 2009).

Para além das coordenações no bloco, o caso argentino ilustra bem os impactos positivos dos protocolos internacionais na legislação doméstica. A lei de Prevención y Sanción de la Trata de Personas y Asistencia a sus Víctimas, promulgada no mesmo mês da 
Declaração de Montevidéu, oferece, junto ao combate ao delito, um olhar especial à assistência às vítimas, tendo como princípio norteador de suas definições o Protocolo de Palermo (SOARES; SOUZA, 2011).

Na conjuntura do Brasil, embora com problemas, o País avançou significativamente no combate ao tráfico humano desde 2000. Neste ano, o Planalto foi advertido pela OEA pelo fato de a agenda brasileira não contemplar em nenhum aspecto o tráfico de pessoas. A partir dessa constatação, o Brasil passou a reiterar nos foros internacionais o total repúdio a todas as formas de tráfico de seres humanos. No plano interno, passou a elaborar leis e diretrizes para o combate deste crime. Em 2006 foi aprovada a Política Nacional de Enfrentamento ao Tráfico de Pessoas (PNETP), Decreto $n^{\circ}$ 5.948/2006 (BRASIL, 2006), com definições baseadas no Protocolo de Palermo.

Em linhas gerais, o PNETP propõe o enfrentamento do tráfico de pessoas sob diferentes óticas, com monitoramento e avaliação periódica das atividades, além de integrar a questão às elaborações de políticas públicas. O plano envolve 13 ministérios, além da participação da sociedade civil por meio de ONGs. Dessa forma, o plano possibilitou que a União possa atuar em parceria com municípios e unidades da Federação para coordenar suas ações, tanto para punir os infratores quanto para dar suporte às vítimas (SOARES; SOUZA, 2011).

Em fevereiro de 2013 foi anunciado pela presidência da República o PNETP II, com diretrizes e objetivos estruturalmente semelhantes ao primeiro. Dois anos após sua implantação, o Escritório das Nações Unidas sobre Drogas e Crimes(UNODC) - órgão ligado à ONU para monitorar as ações em relação a crimes internacionais - divulgou um balanço das ações do projeto, pelo qual, das 115 metas previstas, 54 podem ser consideradas ótimas e duas com péssimo progresso.

Nesse cenário, é impossível ignorar as mudanças conceituais e em políticas públicas decorrentes do Protocolo de Palermo que, embora não completas, são um passo na direção certa ao combate ao tráfico de pessoas, que reflete de maneira decisiva no transporte de imigrantes ilegais. Para além da contradição inerente entre a criminalização da imigração versus ocombate ao tráfico de humanos, ao chegar aos parlamentos nacionais, essas políticas de ampliação de direitos e proteção às vítimas sofrem resistência. A situação no Brasil explicita essa questão, uma vez que empresas ligadas ao trabalho análogo à escravidão doaram para a campanha de 61 candidatos nas últimas eleições. Assim, leis mais severas ao tráfico e à exploração da mão de obra muitas vezes são abrandadas ou arquivadas. Para 
avançar de forma mais incisiva no tema, mostra-se necessária também a participação da sociedade civil e uma maior pressão por parte dos blocos ou organizações internacionais.

\section{Conclusão}

Com base em todo o exposto, é possível inferir que, a partir do início do século XXI, por fatores de convergência política regional e da própria intensificação dos fluxos migratórios no continente, o Mercosul passa a abordar a temática dos direitos dos estrangeiros de forma distinta, com mais ênfase na cooperação e em seu aspecto social.

No caso brasileiro, pouco se alterou a relação com os imigrantes do bloco. Sem políticas públicas especiais, o que se destacou foi a anistia migratória, de 2009, que regularizou dezenas de milhares de estrangeiros. Porém, o paradigma vigente sobre o tema das migrações no governo brasileiro continuou estático nas últimas décadas, imobilizado pelas proibições positivadas pelo Estatuto do Estrangeiro e pela falta de vontade política em estimular o debate de reformas migratórias no âmbito institucional ou dos movimentos sociais.

Dessa forma, embora tenham ocorrido claros avanços na ratificação de importantes acordos nos âmbitos internacional e regional, o fato de o maior país do Mercosul não ter avançado significativamente no assunto, somado à falta de mecanismos de controle das políticas públicas aprovadas em conjunto no bloco, faz com o que o simples avanço jurídico não tenha se concretizado em ganhos socioeconômicos para a população migrante latina trabalhadora que se assenta em países vizinhos.

Assim, mesmo que alguns países como a Argentina, tenham consolidado políticas públicas na direção certa, torna-se evidente que não foi alterado o paradigma dominante sobre o tema das migrações no continente: mercadológico, punitivo, segregacionista e seletivo, embasado nas políticas neoliberais. Se nos últimos quinze anos os avanços não se concretizaram em uma mudança de paradigma, atualmente o cenário não é oportuno para tais mudanças. A falta de convergência entre os chefes de Estado, somada à crise econômica na região e as turbulências políticas no Brasil, aponta para um cenário de estagnação nos avanços sociais do tratamento da imigração latina dentro do Mercosul e, provavelmente, colocará a pauta para fora do centro das mesas de discussão nos próximos anos. 
Saindo das elaborações meramente acadêmicas, os estudos de campo e relatos sobre a situação de vulnerabilidade do trabalhador migrante latino no Brasil comprovam que pouco mudou na relação do Estado com o estrangeiro nas últimas décadas. Primeiramente, a condição de subemprego ainda é a mais comum entre os trabalhadores latinos nas grandes cidades do Cone Sul, variando conforme as necessidades das metrópoles e da origem nacional. De qualquer forma, o que não se altera é a exploração da "mais-valia étnica", relação de poder específica do novo marco global das relações de produção capitalista (BRUNO, 2008, p.13-15).

Essa mais-valia étnica, na prática, como é denunciada pelo Centro de Apoio ao Migrante (Cami), em São Paulo, traduz-se em salários próximos à metade do saláriomínimo nacional, jornadas de trabalho com média de 84 horas por semana, com famílias acomodadas, muitas vezes, em cortiços ou, até mesmo, no próprio local de trabalho. Com isso, para além da extrema vulnerabilidade social, esses trabalhadores convivem com a violência moral e, muitas vezes, até física, o que agrava os casos de desagregação familiar, doenças graves e distúrbios psicológicos (ILLES; TIMÓTEO; FIORUCCI, 2008; CACCIAMALI; AZEVEDO, 2005).

Nesse contexto, como aponta o texto de Fernandes (2013), a falta de políticas públicas estruturais - principalmente no âmbito previdenciário e trabalhista - faz com que a organização da sociedade civil estrangeira seja o meio mais recorrido e eficaz para a promoção de eventos comunitários, festividades e assistencialismo para os trabalhadores em condição de risco. Esse fato evidencia-se no caso da comunidade boliviana em São Paulo, detentora de diversas associações culturais de distintas orientações que promovem festas andinas, detêm meios de comunicação em língua local, além de organizarem-se de outras formas com o intuito de ocupar o espaço público.

Ao final, tem-se a impressão de que, a depender apenas do Estado, seja no âmbito nacional, seja no âmbito comunitário, o respeito aos direitos dos imigrantes trabalhadores restará insuficiente ainda por longos anos. E enquanto não houver mecanismos de controle eficientes dentro do Mercosul, o panorama dificilmente se alterará e esses trabalhadores continuarão a ter os mais básicos direitos fundamentais violados diariamente.

\footnotetext{
Mais-valia étnica define-se pela exploração da jornada de trabalho, facilmente estendida de forma arbitrária pelo empregador, sem o pagamento proporcional ou consentimento do empregado. Esse tipo de exploração apenas se viabiliza pela criação de nichos trabalhistas, especializados em confecções específicas e na ilegalidade desses imigrantes, que não podem recorrer à ajuda estatal (BRUNO, 2008, p.13-15).
} 


\section{Referências bibliográficas}

ARGENTINA. Ministerio de Justicia y Seguridad de la Província de Buenos Aires. Ley $\mathbf{N}^{\mathbf{0}}$ 26.364 Prevención y sanción de la Trata de Personas y asistencia a sus víctimas. Decreto 978/10 Creación de la Comisión Provincial para la prevención y erradicación de la Trata de Personas. Buenos Aires: Coordinación de Políticas de Género, 2011. Disponível em: $<$ https://www.unicef.org/argentina/spanish/LEY26364imprime.pdf>. Acesso em 25 nov. 2016.

ARGENTINA, Protocolo contra el tráfico ilícito de migrantes por tierra, mar y aire, Boletín Oficial Del Estado num. 295. Disponível em $<$ https://www.iberred.org/sites/default/files/2.4.-protocolo-trfic-ilicto-mi-grantes-ny-15-nov00_0.pdf>. Acesso em 25 nov. 2016.

BIJOS, C. A insuficiência das ações brasileiras no enfrentamento ao tráfico internacional de pessoas. Revista do Mestrado em Direito, Brasília, v. 3, n. 2, 2009. Disponível em: $<$ http://portalrevistas.ucb.br/index.php/rvmd/article/viewFile/2562/1555>. Acesso em 8 abr. 2016.

BRASIL. Decreto n ${ }^{\circ}$ 3.927, de 19 de setembro de 2001. Promulga o Tratado de Amizade, Cooperação e Consulta, entre a República Federativa do Brasil e a República Portuguesa, celebrado em Porto Seguro em 22 de abril de 2000. Diário Oficial da União, Brasília, 20 set. 2001.

BRASIL. Decreto n ${ }^{\circ} 5.016$ de 12 de março de 2004. Promulga a Convenção das Nações Unidas contra o Crime Organizado Transnacional Relativo à Prevenção, Repressão e Punição do Tráfico de Pessoas, em Especial Mulheres e Crianças. Diário Oficial da União, Brasília, 15 mar. 2004a.

BRASIL. Decreto 5.017, 12 de março de 2004. Promulga o Protocolo Adicional à Convenção das Nações Unidas contra o Crime Organizado Transnacional Relativo à Prevenção, Repressão e Punição do Tráfico de Pessoas, em Especial Mulheres e Crianças.Diário Oficial da União, Brasília, 15 mar. 2004b.

BRASIL. Decreto 5.948, 26 de outubro de 2006. Aprova a Política Nacional de Enfrentamento ao Tráfico de Pessoas e institui Grupo de Trabalho Ministerial com o objetivo de elaborar Plano Nacional de Enfrentamento ao Tráfico de Pessoas.Diário Oficial da União, Brasília, 27 out. 2006.

BRASIL. Secretaria Nacional de Justiça. II Plano Nacional de Enfrentamento ao Tráfico de Pessoas. Brasília: Ministério da Justiça, 2013. Disponível em: $<$ https://www.unodc.org/documents/lpo-brazil/noticias/2013/04/2013-0408_Folder_IIPNETP_Final.pdf >. Acesso em 25 nov. 2016.

BRUNO, S. Inserción laboral de los migrantes paraguayos en Buenos Aires. Una revisión de categorías: desde el "nicho laboral" a la "plusvalía étnica". Revista Población y Desarrollo, Asunción, n. 36, 2008. Disponível em:

<http://paraguay.sociales.uba.ar/files/2011/07/Bruno_08.pdf>. Acesso em 19 abr. 2014.

CACCIAMALI, M. C.; AZEVEDO, F. A. G. Entre o tráfico humano e a opção da mobilidade social: os imigrantes bolivianos na cidade de São Paulo. Cadernos Prolam, São Paulo, v. 1, 2005. Disponível em: <http://www.revistas.usp.br/prolam/article/view/81803/85109>. Acesso em 10 jun. 2016. 
CÂMARA, A. R. Fluxos migratórios para o Brasil no início do século XXI: respostas institucionais brasileiras. 2014. Dissertação (Mestrado em Relações Internacionais) - Instituto de Relações Internacionais, Universidade de Brasília, Brasília, DF. Disponível em: <http://repositorio.unb.br/bitstream/10482/18422/1/2014_AtilaRabeloTavaresdaCamara.pdf>. Acesso em 2 abr. 2016.

CAIXA e Prefeitura de São Paulo ajudam a bancarizar imigrantes, 15 abr. 2014. Disponível em: <http://www20.caixa.gov.br/Paginas/Noticias/Noticia/Default. aspx?newsID=631>. Acesso em 14 abr. 2016

CONECTAS, $\mathbf{1}^{\mathbf{0}}$ de maio: Dia de todos os trabalhadores, 30 abr. 2015. Disponível em: $<$ http://www.conectas.org/pt/acoes/politica-externa/noticia/34890-1o-de-maio-dia-de-todosos-trabalhadores>. Acesso em 10 abr. 2016.

CULPI, L. A evolução da política migratória no Mercosul entre 1991 e 2014. Revista Conjuntura Global, Curitiba, v. 4, n. 3, 2015. Disponível em: $<$ http://ojs.c3sl.ufpr.br/ojs/index.php/conjgloblal/article/view/45387/27563>. Acesso em 7 abr. 2016.

DIÓGENES, Juliana, Centro de São Paulo ganhará dois abrigos para imigrantes, 29 mai. 2015. Disponível em <http://sao-paulo.estadao.com.br/noticias/geral,centro-de-sao-pauloganhara-dois-abrigos-para-imigrantes,1696392>. Acesso em 4 de abr. 2016.

FERNANDES, D. O Brasil e a migração internacional no século XXI: notas introdutórias. In: PRADO, E. J. P do; COELHO, R. (Orgs.). Migrações e trabalho. Brasília: Ministério Público do Trabalho, 2015. Disponível em: <http://portal.mpt.mp.br/wps/wcm/connect/portal_mpt/2744ae77-4584-4d92-b91d185adc09ba87/Livro_Migracoes_e_TrabalhoWEB.pdf?MOD=AJPERES\&CONVERT_TO=u rl\&CACHEID=2744ae77-4584-4d92-b91d-185adc09ba87>. Acesso em 8 abr. 2016.

FERNANDES, G. A. A. L. Direito à cidadania: um estudo sobre os imigrantes bolivianos em São Paulo e Buenos Aires e as principais leis migratórias do Brasil e da Argentina. São Paulo: USP, 2013.

GIOVANELLA, L. et al. Saúde nas fronteiras: acesso e demandas de estrangeiros e brasileiros não residentes ao SUS nas cidades de fronteira com países do Mercosul na perspectiva dos secretários municipais de saúde. Cadernos de Saúde Pública, Rio de Janeiro, v. 23, 2007. Disponível em: <http://www.scielo.br/pdf/csp/v23s2/13.pdf>. Acesso em 30 mar. 2016.

ILLES, P.; TIMÓTEO, G. L. S. T.; FIORUCCI, E. Tráfico de pessoas para fins de exploração do trabalho na cidade de São Paulo. Cadernos Pagu, Campinas, n. 31, 2008. Disponível em: <http://www.scielo.br/pdf/cpa/n31/n31a10.pdf〉. Acesso em 2 abr. 2016.

LOCATELLI, Piero, Trabalho escravo financiou 61 candidatos, 2 out. 2014. Disponível em: <http://www.cartacapital.com.br/politica/empresas-com-trabalho-escravo-financiaram61-candidatos-820.html>. Acesso em 7 abr. 2016.

LUSSI, C. Formulação legal e políticas públicas no trato das migrações nacionais e internacionais. In: PRADO, E. J. P do; COELHO, R. (Orgs.). Migrações e trabalho. Brasília: Ministério Público do Trabalho, 2015. Disponível em: <http://portal.mpt.mp.br/wps/wcm/connect/portal_mpt/2744ae77-4584-4d92-b91d- 
185adc09ba87/Livro_Migracoes_e_TrabalhoWEB.pdf?MOD=AJPERES\&CONVERT_TO=u rl\&CACHEID=2744ae77-4584-4d92-b91d-185adc09ba87>. Acesso em 2 abr. 2016.

OIT, Trabalho Forçado ou Obrigatório: convenção $\mathbf{N}^{0}$ 29. Disponível em: <http://www.oitbrasil.org.br/node/449>. Acesso em 25 nov. 2016.

OIT, Abolição do Trabalho Forçado: convenção N¹05. Disponível em: <http://www.oit.org.br/node/469>. Acesso em 25 nov. 2016.

OIT, Trabalhadores Migrantes (Revista): convenção N⿳907. Disponível em:<http://www.oitbrasil.org.br/node/523>. Acesso em 25 nov. 2016.

OIT, Convenção Sobre as Imigrações Efetuadas em Condições Abusivas e Sobre a Promoção da Igualdade de Oportunidades e de Tratamento dos Trabalhadores Migrantes: convenção N¹43. Disponível em:<http://www.oitbrasil.org.br/content/conven\%C3\%A7\%C3\%A3o-sobreimigra\%C3\%A7\%C3\%B5es-efectuadas-em-condi\%C3\%A7\%C3\%B5es-abusivas-e-sobrepromo\%C3\%A7\%C3\%A3o-da-igualdade-de> Acesso em 25 nov. 2016.

OIT - ORGANIZAÇÃO INTERNACIONAL DO TRABALHO. Cooperação e coordenação policial no Mercosul e Chile para o enfrentamento ao tráfico de pessoas. Brasília: Organização Internacional do Trabalho, 2009. Disponível em: <http://www.oitbrasil.org.br/sites/default/files/topic/tip/pub/cooperacao_coordenacao_policial _375.pdf>. Acesso em 5 abr. 2016.

PATARRA, N. L. Migrações internacionais de e para o Brasil contemporâneo: volumes, fluxos, significados e políticas. São Paulo em Perspectiva, São Paulo, v. 19, n. 3, 2005. Disponível em: <http://www.scielo.br/pdf/spp/v19n3/v19n3a02.pdf>. Acesso em 10 mar. 2016.

PERERA, M. La movilidad del factor trabajo en el Mercosur. Montevideo: Centro de Investigaciones Económicas, 2010. Disponível em: <http://www.cinve.org.uy/wpcontent/uploads/2013/01/MOV-TRABAJO-CINVE.pdf>. Acesso em 6 abr. 2016.

SALA, G. A.; CARVALHO, J. A. M. A presença de imigrantes de países do cone sul no Brasil: medidas e reflexões. Revista Brasileira de Estudos de População, Rio de Janeiro, v. 25, n. 2, 2008. Disponível em: 〈http://www.scielo.br/pdf/rbepop/v25n2/v25n2a06.pdf>. Acesso em 7 abr. 2016.

SOARES, M. L. Q.; SOUZA, M. C. de. O enfrentamento ao tráfico de pessoas no âmbito do Mercosul. Revista Sequência: Estudos Jurídicos e Políticos, Florianópolis, v. 32, n. 63, 2011. Disponível em:

<http://www.egov.ufsc.br/portal/sites/default/files/o_enfrentamento_ao_trafico_de_pessoas_n o_ambito_do_mercosul.pdf >. Acesso em 10 abr. 2016.

SOUCHAUD, S. A confecção: nicho étnico ou nicho econômico para a imigração latinoamericana em São Paulo? In: BAENINGER, R. (Org.). Imigração boliviana no Brasil. Campinas: Nepo/Unicamp, Fapesp, CNPq, Unfpa, 2012. Disponível em: <http://hal.ird.fr/ird00686112/document>. Acesso em: 11 abr. 2016.

UNODC, Prevenção ao Crime e Justiça Criminal: marco legal. Disponível em:< https://www.unodc.org/lpo-brazil/pt/crime/marco-legal.html>. Acessado em 25 nov. 2016. 
UNODC, Secretário Nacional de Justiça avalia ações do II Plano Nacional de Enfrentamento ao Tráfico de Pessoas. Disponível em: <https://www.unodc.org/lpobrazil/pt/frontpage/2015/01/secretaria-nacional-de-justica-avalia-ii-plano-nacional-deenfrentamento-ao-trafico-de-pessoas.html>. Acesso em 10 abr. 2016.

VICHICH, N. P. Las políticas migratorias regionales y los derechos de los trabajadores: perspectivas y desafíos. In: PRADO, E. J. P do; COELHO, R. (Orgs.). Migrações e trabalho. Brasília: Ministério Público do Trabalho, 2015. Disponível em: <http://portal.mpt.mp.br/wps/wcm/connect/portal_mpt/2744ae77-4584-4d92-b91d185adc09ba87/Livro_Migracoes_e_TrabalhoWEB.pdf?MOD=AJPERES\&CONVERT_TO=u rl\&CACHEID=2744ae77-4584-4d92-b91d-185adc09ba87>. Acesso em 8 abr. 2016.

VILELA, E. M.; SAMPAIO, D. P. Um olhar sobre as autorizações de permanência a estrangeiros no Brasil, entre 2005 e 2011. Revista Brasileira de Estudos de População, Rio de Janeiro, v. 32, n. 1, 2015. Disponível em:

<http://rebep.org.br/index.php/revista/article/view/693/pdf_627>. Acesso em 10 abr. 2016. 